\title{
Optimasi Waktu dan Biaya Menggunakan Metode Time Cost Trade Off pada Proyek Access Road Construction and Soil Clean Up
}

\author{
Suherman $^{1}$, Qori Paradise Hariono ${ }^{2}$ \\ 1,2 Jurusan Teknik Industri, Fakultas Sains dan Teknologi, UIN Sultan Syarif Kasim Riau \\ Jl. HR. Soebrantas No. 155 Simpang Baru, Panam, Pekanbaru, 28293 \\ Email: suher.aje@yahoo.com, Qori.Paradise@ymail.com
}

\begin{abstract}
Abstrak
Salah satu proyek yang dijalankan oleh PT.Ikhtiar Mulia Kontruksi adalah proyek Access Road Construction and Soil Clean Up. Proyek Access Road Contruction and Soil Clean Up merupakan suatu proyek pengerjaan pembuatan akses jalan masuk dan pembersihan daerah area yang terkontaminasi oleh limbah minyak. Pada proyek sebelumnya terjadi keterlambatan penyelesaian proyek mengakibatkan adanya pertambahan biaya proyek sebesar $0,20 \%$. Pada proyek access road construction and soil clean up yang akan diteliti, proyek direncanakan dimulai pada tanggal 1 maret 2016, namun dalam pelaksanaannya proyek mengalami penundaan pelaksanaan hingga 7 maret 2016. Penelitian ini bertujuan untuk memberikan alternatif kepada perencana proyek untuk dapat menyusun perencanaan yang terbaik sehingga dapat mengoptimalkan waktu dan biaya dalam menyelesaikan suatu proyek, dengan melakukan perbandingan penambahan jam kerja, tenaga kerja, serta kapasitas alat yang digunakan. Penelitian ini menggunakan metode time cost trade off dengan bantuan software Microsoft Project 2007, untuk penyusunan jaringan kerja dan melihat lintasan kritis pada proyek. Dari hasil penelitian, didapat waktu dan biaya yang optimal untuk proyek yaitu dengan melakukan penambahan alat dengan durasi proyek 100 hari kerja dengan biaya total Rp. 4.895.673.552.
\end{abstract}

Kata Kunci: Time Cost Trade Off, Crash Duration, Crash Cost, Cost Slope

\section{Latar Belakang}

Proyek dapat diartikan sebagai kegiatan yang berlangsung dalam jangka waktu yang terbatas dengan mengalokasikan sumber daya tertentu dan dimaksudkan untuk menghasilkan produk atau deliverable yang kriteria mutunya telah digariskan dengan jelas (Soeharto, 1999). Dalam menjalankan suatu proyek, untuk kelancarannya membutuhkan pengelolaan manajemen yang baik dari awal hingga proyek berakhir. Bila dalam pelaksanaan proyek mengalami kegagalan, maka akan mengakibatkan gagalnya pencapaian tujuan utama proyek dan menyebabkan terjadinya pemborosan terhadap waktu dan biaya. Kegagalan pelaksanaan proyek sering disebabkan karena kurang terencananya kegiatan proyek, pengendalian yang kurang efektif sehingga kegiatan proyek tidak efisien.

Pelaksanaan proyek konstruksi memiliki rangkaian kegiatan, mulai dari perencanaan (pengaturan sumber daya tenaga kerja, biaya, bahan, waktu dan sebagainya) sampai pada pelaksanaan pengaturan penjadwalan, mengendalikan dan mengontrol proyek dengan baik. Perencanaan kegiatan-kegiatan proyek merupakan suatu hal yang penting, karena perencanaan ini merupakan dasar dari suatu proyek agar proyek dapat berjalan dengan lancar dan selesai pada waktu yang telah ditetapkan.
PT.Ikhtiar Mulia Kontruksi adalah kontraktor yang yang bergerak dalam bidang proyek kontruksi seperti pembangunan gedung, jembatan, jalan, taman, instalasi, pengembangan wilayah, pertambangan minyak, gas, panas bumi, komunikasi, dan pengembang perumahan. Salah satu proyek yang dikerjakan oleh PT.Ikhtiar Mulia Kontruksi adalah proyek Access Road Construction and Soil Clean Up. Proyek Access Road Contruction and Soil Clean Up merupakan suatu proyek pengerjaan pembuatan akses jalan masuk dan pembersihan daerah area yang terkontaminasi oleh limbah minyak.

Pada proyek sebelumnya yang dilaksanakan dari tanggal 4 september sampai dengan 1 Januari 2016, mengalami keterlambatan pada penyelesaian proyek. Kurva $\mathrm{S}$ proyek dapat dilihat pada gambar 1.1.

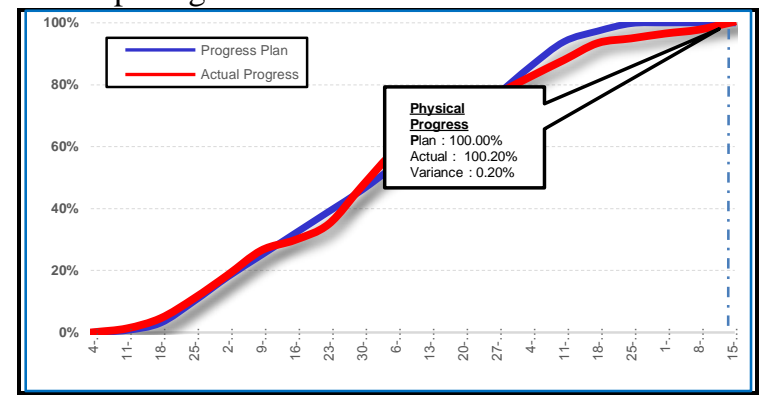

Gambar 1.1 S-Curve Plan-Actual Physical Progress 
Berdasarkan gambar 1.1 diatas dapat dilihat bahwa proyek direncanakan selesai pada tanggal 1 Januari 2016, namun dalam pelaksanaannya proyek mengalami keterlambatan penyelesaian hingga 15 januari 2016.

Pada proyek access road construction and soil clean up yang akan diteliti, proyek dilaksanakan dari tanggal 1 maret sampai dengan 22 agustus 2016, dengan nilai kontrak proyek adalah Rp.5.001.878.050. Adapun Kurva S perencanaan proyek ini dapat dilihat pada gambar 1.2.

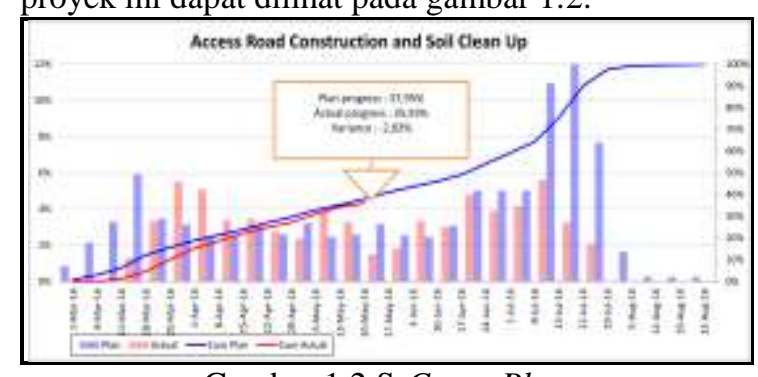

Gambar 1.2 S-Curve Plan

Berdasarkan gambar 1.2 diatas dapat dilihat bahwa proyek direncanakan dimulai pada tanggal 1 maret 2016, namun dalam pelaksanaannya proyek mengalami penundaan pelaksanaan hingga 7 maret 2016.

Hasil observasi dan wawancara terhadap manajer proyek, keterlambatan penyelesaian proyek ini disebabkan oleh beberapa faktor yaitu keadaan cuaca yang tidak menentu, kerusakan alat yang mengharuskan alat diperbaiki terlebih dahulu, keadaan lapangan seperti berlumpur dan tergenang air, hingga masyarakat sekitar yang melakukan aksi demo menolak adanya kegiatan proyek dilingkungan mereka. Adapun persentase faktor keterlambatan dapat dilihat pada tabel 1.1.

Tabel 1.1 Persentase Faktor Keterlambatan

\begin{tabular}{|c|l|c|c|}
\hline No & \multicolumn{1}{|c|}{ Faktor } & Hari & Persentase \\
\hline 1 & Cuaca & $2 \frac{1}{2}$ & $35 \%$ \\
\hline 2 & Kerusakan Alat & 2 & $30 \%$ \\
\hline 3 & $\begin{array}{l}\text { Keadaan } \\
\text { Lapangan }\end{array}$ & 2 & $30 \%$ \\
\hline 4 & Demo & $1 / 2$ & $5 \%$ \\
\hline
\end{tabular}

Untuk mengembalikan tingkat kemajuan proyek ke rencana semula diperlukan suatu upaya percepatan proyek dengan menggunakan metode Time Cost Trade Off. Metode time cost trade off (metode pertukaran waktu dan biaya) memberikan alternatif kepada perencana proyek untuk dapat menyusun perencanaan yang terbaik sehingga dapat mengoptimalkan waktu dan biaya dalam menyelesaikan suatu proyek, serta mengefisiensikan sumber daya yang diperlukan dengan pertambahan biaya yang paling optimum. Fokus utama dari metode time cost trade off ini adalah kegiatan-kegiatan proyek yang berada pada lintasan kritis dengan menambahkan alternatif-alternatif yang ada agar kegiatan yang berada pada lintasan kritis dapat diselesaikan tepat waktu. Upaya percepatan dengan metode time cost trade off ini dilakukan dengan melakukan penambahan jam kerja, grup kerja, serta kapasitas alat yang digunakan.

Proses pengerjaan dengan menggunakan metode time cost trade off ini menggunakan bantuan software Microsoft Project 2007, guna membantu memudahkan dalam proses penyusunan jaringan kerja dan melihat lintasan kritis pada proyek.

Tujuan dilakukan penelitian ini adalah untuk mengetahui durasi dan biaya yang optimal dalam penyelesaian proyek dengan melakukan perbandingan terhadap penambahan jam kerja, grup kerja, dan kapasitas alat.

\section{Tinjauan Pustaka}

\section{Proyek}

Proyek dapat didefinisikan sebagai proses pembuatan produk atau jasa yang bersifat unik dalam rentang waktu terbatas. Sebuah proyek memiliki awal dan akhir yang telah ditentukan dan baru dianggap berakhir jika tujuan dari proyek tersebut telah tercapai. Sifat unik dari produk atau jasa yang dihasilkan berarti bahwa hasil dari proyek memiliki perbedaan dengan produk atau jasa lain yang sejenis. Sebagai contoh terdapat ribuan gedung yang dibuat melalui proyek konstruksi akan tetapi masing-masing gedung tersebut memiliki perbedaaan antara satu dengan lainnya. Oleh karena itu, produk atau jasa yang akan diproduksi melalui proyek dikembangkan dengan detail dan mendalam secara bertahap. Proyek termasuk salah satu strategi proses produksi dalam bidang kajian sistem produksi.

\section{Penjadwalan Proyek}

Penjadwalan dalam pengertian proyek konstruksi merupakan perangkat untuk menentukan aktivitas yang diperlukan untuk menyelesaikan suatu proyek dalam urutan serta kerangka waktu tertentu, dalam mana setiap aktivitas harus dilaksanakan agar proyek selesai tepat waktu dengan biaya yang ekonomis (Callahan, 1992). Penjadwalan meliputi tenaga kerja, material, peralatan, keuangan, dan waktu. Dengan penjadwalan yang tepat maka beberapa macam kerugian dapat dihindarkan seperti keterlambatan, pembengkakan biaya, dan perselisihan

\section{Kurva S}

Kurva $S$ adalah sebuah grafik yang dikembangkan oleh Warren T. Hanumm atas dasar pengamatan terhadap sejumlah besar proyek sejak awal hingga akhir proyek. Kurva $\mathrm{S}$ dapat 
menunjukan kemajuan proyek berdasarkan kegiatan, waktu dan bobot pekerjaan yang direpresentasikan sebagai persentase kumulatif dari seluruh kegiatan proyek. Visualisasi Kurva S dapat memberikan informasi mengenai kemajuan proyek dengan membandingkannya terhadap jadwal rencana.

\section{Microsoft Project}

Microsoft project adalah suatu paket program sistem perencanaan suatu proyek. Dengan bantuan program ini seorang pimpinan proyek akan dibantu untuk memperhitungkan jadal suatu proyek secara terperinci pekerjaan demi pekerjaan. Microsoft project mampu menghubungkan antara suatu subproyek dengan subproyek yang lain yang saling berkaitan, kemudian mengelola keseluruhan proyek tersebt ke dalam suatu file proyek.

\section{Lintasan Kritis}

Jalur kritis terdiri dari rangkaian kegiatan kritis, dimulai dari kegiatan pertama sampai pada kegiatan terakhir proyek (Soeharto, 1999). Lintasan kritis (Critical Path) melalui aktivitas-aktivitas yang jumlah waktu pelaksanaannya paling lama. Jadi, lintasan kritis adalah lintasan yang paling menentukan waktu penyelesaian proyek secara keseluruhan.

\section{Rencana Anggran Biaya (RAB)}

Rencana anggaran biaya proyek diperlukan untuk melakukan pemampatan setelah menyusun network diagram. Rencana anggaran biaya proyek berisi tentang volume, harga satuan dan harga dari tiap-tiap pekerjaan. Selain rencana anggaran proyek diperlukan juga analisa harga satuan. Di dalam analisa harga satuan dapat dilihat jumlah bahan, jumlah tenaga kerja untuk setiap pekerjaan.

\section{Produktifitas Pekerja}

Produktivitas didefinisikan sebagai rasio antara output dan input, atau dapat dikatakan sebagai rasio antara hasil produksi dengan total sumber daya yang digunakan. Di dalam proyek konstruksi, rasio dari produktivitas adalah nilai yang diukur selama proses kontruksi; yang dapat dipisahkan menjadi biaya tenaga kerja, biaya material, metode, dan alat. Kesuksesan dari suatu proyek konstruksi salah satunya tergantung pada efektifitas pengelolaan sumber daya, dan pekerja adalah salah satu sumber daya yang tidak mudah untuk dikelola. Upah yang diberikan sangat tergantung pada kecakapan masing-masing pekerja dikarenakan setiap pekerja memiliki karakter masing-masing yang berbeda-beda satu sama lainnya.

Produktivitas harian $\quad=\frac{\text { Volume }}{\text { Durasi Normal }}$
Produktivitas tiap jam $\quad=\frac{\text { Produktifitas Harian }}{\text { Jam Kerja per Hari }}$

Produktifitas harian

sesudah crash $=($ Jam kerja perhari $\mathrm{x}$ Produktifitas tiap jam $)+(\mathrm{a} \times \mathrm{b} \times$ Produktifitas tiap jam)

$\mathrm{a}=$ Lama penambahan jam kerja (lembur)

$\mathrm{b}=$ Koefisein penurunan produktivitas akibat penambahan jam kerja (lembur)

Crash Duration $=\frac{\text { Volume }}{\text { Produktivitas Harian Sesudah crash }}$

Biaya Tambahan Pekerja (Crash Cost) dan Cost Slope Penambahan waktu kerja akan menambah besar biaya untuk tenaga kerja dari biaya normal tenaga kerja. Berdasarkan Keputusan Menteri Tenaga Kerja dan Transmigrasi Republik Indonesia Nomor KEP. 102/MEN/VI/2004 bahwa upah penambahan kerja bervariasi. Pada penambahan waktu kerja satu jam pertama, pekerja mendapatkan tambahan upah 1,5 kali upah perjam waktu normal dan pada penambahan jam kerja berikutnya maka pekerja akan mendapatkan 2 kali upah perjam waktu normal.

Perhitungan untuk biaya tambahan pekerja dapat dirumuskan sebagai berikut ini:

1. Normal ongkos pekerja perhari

$=$ Produktivitas harian $\mathrm{x}$ Harga satuah upah pekerja

2. Normal ongkos pekerja perjam

= Produktivitas perjam $\mathrm{x}$ harga satuan upah pekerja

3. Biaya lembur pekerja

$=(1,5 \mathrm{x}$ upah $1 \mathrm{jam}$ penambahan jam kerja (lembur) pertama $)+(2 x \mathrm{n} x$ upah 1 jam normal untuk penambahan jam kerja (lembur) berikutnya)

Dimana :

$\mathrm{n}=$ Jumlah penambahan jam kerja (lembur)

4. Crash Cost pekerja perhari

$=($ Jam kerja perhari $\mathrm{x}$ normal cost pekerja $)+(\mathrm{n} x$ biaya lembur perjam)

$$
\text { 5. Cost Slope }=\frac{\text { Crash cost-Normal cost }}{\text { Durasi Normal-Durasi Crash }}
$$

\section{Time Cost Trade Off}

Sering terjadi suatu proyek harus diselesaikan lebih cepat daripada waktu normalnya. Dalam hal ini pimpinan proyek dihadapkan kepada masalah bagaimana mempercepat penyelesaian proyek dengan biaya minimum. Oleh karena itu perlu dipelajari terlebih dahulu hubungan antara waktu dan biaya. Analisis mengenai pertukaran waktu dan biaya disebut dengan Time Cost Trade Off ( Pertukaran Waktu dan Biaya)

Langkah-langkah kompresi dapat dituliskan sebagai berikut (Indriyani dkk, 2015):

1. Penyusunan jaringan kerja proyek dengan menuliskan cost slope dari masing-masing kegiatan. 
2. Kompresi pada aktifitas yang berada pada lintasan kritis dan mempunyai cost slope

3. Penyusunan kembali jaringan kerja proyek.

4. Mengulangi langkah kedua, langkah kedua akan berhenti bila terjadi pertambahan lintasan kritis dan bila terdapat lebih dari satu lintasan kritis maka langkah kedua dilakukan dengan serentak pada semua lintasan krits dan perhitungan cost slopenya dijumlahkan.

5. Menghentikan langkah komperesi bila terdapat salah satu lintasan kritis dimana aktivitas-aktivitas telah jenuh seluruhnya (tidak mungkin ditekan lagi) sehingga pengendalian biaya telah optimal.

\section{Hasil dan Pembahasan}

\section{Lintasan Kritis Proyek}

Lintasan kritis pada proyek yang didapat dari microsoft project, berikut merupakan rincian kegiatan kritis dapat dilihat pada Gambar 3.1.

Perhitungan Crash Duration, Crash Cost, dan Cost Slope

Perhitungan crash duration, crash cost, cost slope dilakukan pada 3 alternatif, yaitu alternatif 1 (penambahan jam kerja), alternatif 2 (penambahan grup kerja), dan alternatif 3 (penambahan kapasitas alat). Berikut rekapitulasi dari ketiga alternatif yang dapat dilihat pada tabel 3.1 3.2 dan 3.3. 


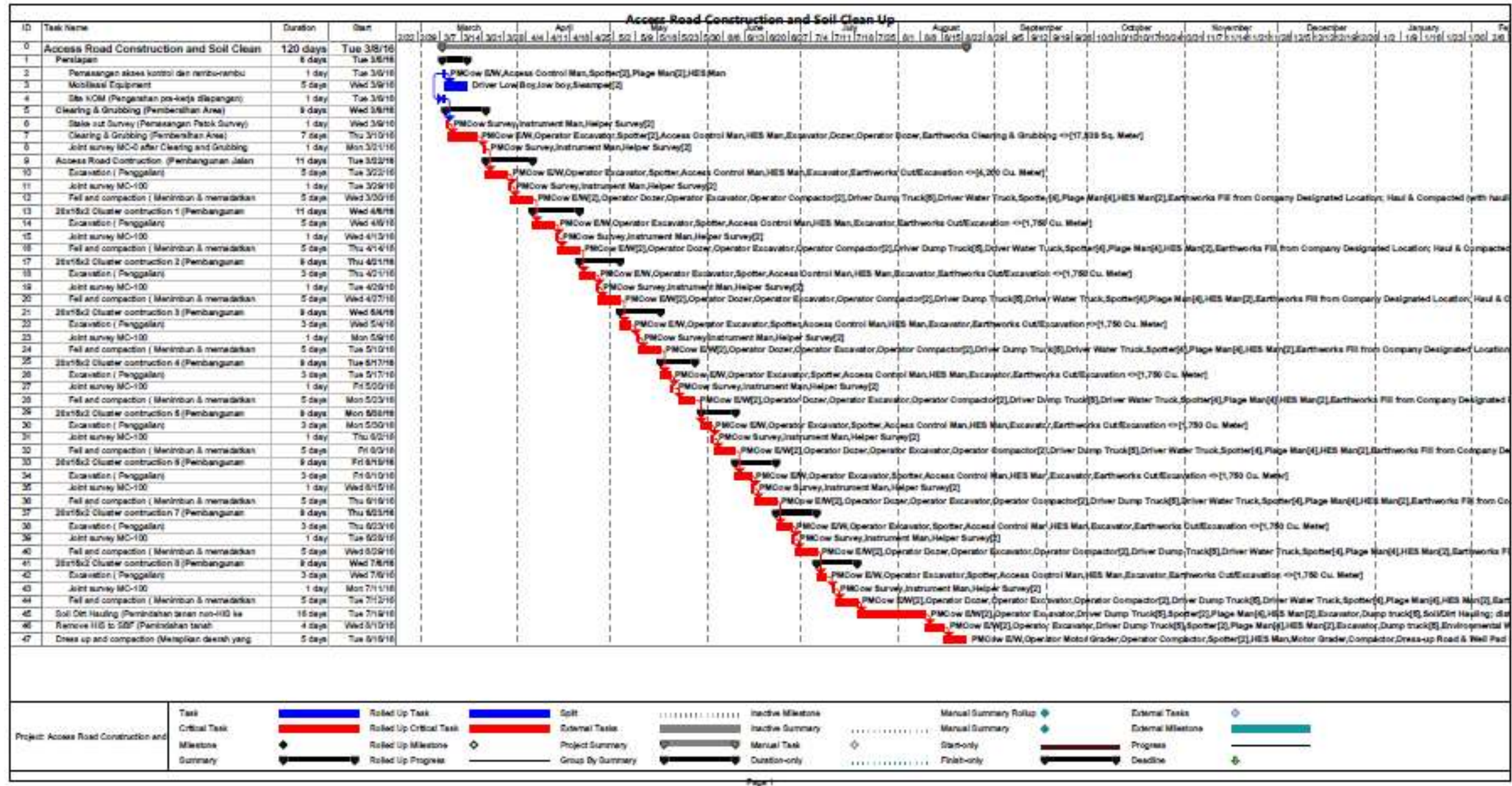

Gambar 3.1 Lintasan Kritis Kegiatan Proyek 

dalam Bidang Teknik Industri

Tabel 3.1 Rekapitulasi Crash Duration Crash Cost dan Cost Slope Alternatif 1 Pekerjaan Lintasan Kritis

\begin{tabular}{|c|c|c|c|c|c|c|c|c|c|c|}
\hline No & Pekerjaan & Volume & $\begin{array}{c}\text { Durasi } \\
\text { Normal } \\
\text { (Hari) }\end{array}$ & $\begin{array}{l}\text { Normal Cost } \\
\quad(\mathrm{Rp})\end{array}$ & $\begin{array}{c}\text { Prouktivitas } \\
\text { Harian }\end{array}$ & $\begin{array}{c}\text { Crash } \\
\text { Duration }\end{array}$ & $\begin{array}{l}\text { Total Upah } \\
\text { Lembur/Hari } \\
(\mathrm{Rp})\end{array}$ & $\begin{array}{l}\text { Crash Cost } \\
\quad(\mathrm{Rp})\end{array}$ & $\begin{array}{c}\text { Crash Cost Total } \\
\text { (Rp) }\end{array}$ & $\begin{array}{l}\text { Cost Slope } \\
\text { (Rp) }\end{array}$ \\
\hline 2.e & $\begin{array}{l}\text { Clearing and } \\
\text { Grubbing } \\
\text { (Pembersihan Area) }\end{array}$ & 17539 & 7 & 158.211 .032 & 2505,57 & 6 & 6.011 .809 & 37.827 .113 & 196.038 .145 & 5.403 .867 \\
\hline $3 . \mathrm{a}$ & $\begin{array}{l}\text { Excavation } \\
\text { (Penggalian) }\end{array}$ & 4200 & 5 & 152.776 .512 & 840 & 4 & 2.876 .201 & 14.381 .005 & 167.157 .517 & 2.230 .163 \\
\hline 3.b & $\begin{array}{l}\text { Fell and Compaction } \\
\text { (Menimbun dan } \\
\text { Memadatkan Tanah) }\end{array}$ & 4200 & 5 & 420.333 .696 & 840 & 4 & 21.111 .775 & 105.558 .875 & 525.892 .571 & 21.111 .771 \\
\hline 4.a & $\begin{array}{l}\text { Excavation } \\
\text { (Penggalian) }\end{array}$ & 1750 & 5 & 68.110 .320 & 350 & 4 & 2.876 .201 & 14.381 .005 & 82.491 .325 & 2.876 .197 \\
\hline 4.c & $\begin{array}{l}\text { Fell and Compaction } \\
\text { (Menimbun dan } \\
\text { Memadatkan Tanah) }\end{array}$ & 1750 & 5 & 206.871 .496 & 350 & 4 & 21.134 .752 & 105.673 .760 & 312.545 .256 & 21.134 .748 \\
\hline $5 . \mathrm{a}$ & $\begin{array}{l}\text { Excavation } \\
\text { (Penggalian) }\end{array}$ & 1750 & 3 & 63.266 .192 & 583,33 & 2 & 2.876 .201 & 8.628 .603 & 71.894 .795 & 2.876 .199 \\
\hline 5.c & $\begin{array}{l}\text { Fell and Compaction } \\
\text { (Menimbun dan } \\
\text { Memadatkan Tanah) }\end{array}$ & 1750 & 5 & 206.871 .496 & 350 & 4 & 21.134 .752 & 105.673 .760 & 312.545 .256 & 21.134 .748 \\
\hline $6 . \mathrm{a}$ & $\begin{array}{l}\text { Excavation } \\
\text { (Penggalian) }\end{array}$ & 1750 & 3 & 63.266 .192 & 583,33 & 2 & 2.876 .201 & 8.628 .603 & 71.894 .795 & 2.876 .199 \\
\hline 6.c & $\begin{array}{l}\text { Fell and Compaction } \\
\text { (Menimbun dan } \\
\text { Memadatkan Tanah) }\end{array}$ & 1750 & 5 & 206.871 .496 & 350 & 4 & 21.134 .752 & 105.673 .760 & 312.545 .256 & 21.134 .748 \\
\hline 7.a & $\begin{array}{l}\text { Excavation } \\
\text { (Penggalian) }\end{array}$ & 1750 & 3 & 63.266 .192 & 583,33 & 2 & 2.876 .201 & 8.628 .603 & 71.894 .795 & 2.876 .199 \\
\hline 7.c & $\begin{array}{l}\text { Fell and Compaction } \\
\text { (Menimbun dan } \\
\text { Memadatkan Tanah) }\end{array}$ & 1750 & 5 & 206.871 .496 & 350 & 4 & 21.134 .752 & 105.673 .760 & 312.545 .256 & 21.134 .748 \\
\hline $8 . \mathrm{a}$ & $\begin{array}{l}\text { Excavation } \\
\text { (Penggalian) }\end{array}$ & 1750 & 3 & 63.266 .192 & 583,33 & 2 & 2.876 .201 & 8.628 .603 & 71.894 .795 & 2.876 .199 \\
\hline
\end{tabular}


Tabel 3.1 Rekapitulasi Crash Duration Crash Cost dan Cost Slope Alternatif 1Pekerjaan Lintasan Kritis (Lanjutan)

\begin{tabular}{|c|c|c|c|c|c|c|c|c|c|c|}
\hline No & Pekerjaan & Volume & $\begin{array}{c}\text { Durasi } \\
\text { Normal } \\
\text { (Hari) }\end{array}$ & $\begin{array}{l}\text { Normal Cost } \\
\qquad(\mathrm{Rp})\end{array}$ & $\begin{array}{c}\text { Prouktivitas } \\
\text { Harian }\end{array}$ & $\begin{array}{c}\text { Crash } \\
\text { Duration } \\
\text { (Hari) }\end{array}$ & $\begin{array}{l}\text { Total Upah } \\
\text { Lembur/Hari } \\
\text { (Rp) }\end{array}$ & $\begin{array}{l}\text { Crash Cost } \\
\quad(\mathrm{Rp})\end{array}$ & $\begin{array}{c}\text { Crash Cost Total } \\
\text { (Rp) }\end{array}$ & $\begin{array}{l}\text { Cost Slope } \\
\quad(\mathrm{Rp})\end{array}$ \\
\hline 8.c & $\begin{array}{l}\text { Fell and Compaction } \\
\text { (Menimbun dan } \\
\text { Memadatkan Tanah) }\end{array}$ & 1750 & 5 & 206.871 .496 & 350 & 4 & 21.134 .752 & 105.673 .760 & 312.545 .256 & 21.134 .748 \\
\hline 9.a & $\begin{array}{l}\text { Excavation } \\
\text { (Penggalian) }\end{array}$ & 1750 & 3 & 63.266 .192 & 583,33 & 2 & 2.876 .201 & 8.628 .603 & 71.894 .795 & 2.876 .199 \\
\hline 9.c & $\begin{array}{l}\text { Fell and Compaction } \\
\text { (Menimbun dan } \\
\text { Memadatkan Tanah) }\end{array}$ & 1750 & 5 & 206.871 .496 & 350 & 4 & 21.134 .752 & 105.673 .760 & 312.545 .256 & 21.134 .748 \\
\hline 10.a & $\begin{array}{l}\text { Excavation } \\
\text { (Penggalian) }\end{array}$ & 1750 & 3 & 63.266 .192 & 583,33 & 2 & 2.876 .201 & 8.628 .603 & 71.894 .795 & 2.876 .199 \\
\hline $10 . c$ & $\begin{array}{l}\text { Fell and Compaction } \\
\text { (Menimbun dan } \\
\text { Memadatkan Tanah) }\end{array}$ & 1750 & 5 & 206.871 .496 & 350 & 4 & 21.134 .752 & 105.673 .760 & 312.545 .256 & 21.134 .748 \\
\hline 11.a & $\begin{array}{l}\text { Excavation } \\
\text { (Penggalian) }\end{array}$ & 1750 & 3 & 63.266 .192 & 583,33 & 2 & 2.876 .201 & 8.628 .603 & 71.894 .795 & 2.876 .199 \\
\hline 11.c & $\begin{array}{l}\text { Fell and Compaction } \\
\text { (Menimbun dan } \\
\text { Memadatkan Tanah) }\end{array}$ & 1750 & 5 & 206.871 .496 & 350 & 4 & 21.134 .752 & 105.673 .760 & 312.545 .256 & 21.134 .748 \\
\hline 12 & $\begin{array}{l}\text { Soil Dirt Hauling } \\
\text { (Pemindahan Tanah } \\
\text { Non-HIS ke Borrow } \\
\text { Pit Area) }\end{array}$ & 14.406 & 16 & 945.973 .328 & 900,375 & 14 & 12.764 .590 & 204.233 .432 & 1.150 .206 .760 & 12.764 .576 \\
\hline 13 & $\begin{array}{l}\text { Remove HIS to SBF } \\
\text { (Pemindahan Tanah } \\
\text { Terkontaminasi ke } \\
\text { Penampungan } \\
\text { Sementara) }\end{array}$ & 3601,44 & 4 & 401.315 .048 & 900,36 & 3 & 12.764 .590 & 51.058 .358 & 452.373 .406 & 17.019 .449 \\
\hline 14 & $\begin{array}{l}\text { Dress and } \\
\text { Compaction } \\
\text { (Merapikan Daerah } \\
\text { yang sudah Tidak } \\
\text { Terkontaminasi) } \\
\end{array}$ & 12.000 & 5 & 61.546 .160 & 2400 & 4 & 4.927 .213 & 24.636 .065 & 86.182 .225 & 4.927.209 \\
\hline
\end{tabular}


Tabel 3.2 Rekapitulasi Crash Duration Crash Cost dan Cost Slope Alternatif 2 Pekerjaan Lintasan Kritis

\begin{tabular}{|c|c|c|c|c|c|c|c|c|c|c|c|}
\hline No & Pekerjaan & Volume & $\begin{array}{c}\text { Durasi } \\
\text { Normal } \\
\text { (Hari) }\end{array}$ & $\begin{array}{l}\text { Total Upah } \\
\text { Grup/Hari } \\
(\mathrm{Rp})\end{array}$ & + Grup & $\begin{array}{c}\text { Produktivitas } \\
\text { +Grup }\end{array}$ & $\begin{array}{c}\text { Crash } \\
\text { Duration } \\
\text { (Hari) }\end{array}$ & $\begin{array}{l}\text { Total Upah } \\
+ \text { Grup/Hari } \\
\quad(\mathrm{Rp})\end{array}$ & $\begin{array}{c}\text { Crash Cost } \\
\quad(\mathrm{Rp})\end{array}$ & $\begin{array}{l}\text { Crash Cost } \\
\text { Total (Rp) }\end{array}$ & $\begin{array}{l}\text { Cost Slope } \\
\quad(\mathrm{Rp})\end{array}$ \\
\hline 2.e & $\begin{array}{l}\text { Clearing and } \\
\text { Grubbing } \\
\text { (Pembersihan Area) }\end{array}$ & 17539 & 7 & 6.011 .809 & 1 & 5011,14 & 4 & 10.125 .152 & 35.438 .032 & 193.649 .064 & 10.125 .152 \\
\hline $3 . \mathrm{a}$ & $\begin{array}{l}\text { Excavation } \\
\text { (Penggalian) }\end{array}$ & 4200 & 5 & 2.876 .201 & 1 & 1680 & 3 & 4.844 .128 & 12.110 .320 & 158.620 .640 & 4.844 .128 \\
\hline 3.b & $\begin{array}{l}\text { Fell and Compaction } \\
\text { (Menimbun dan } \\
\text { Memadatkan Tanah) }\end{array}$ & 4200 & 5 & 21.111 .775 & 1 & 4200 & 3 & 35.596 .832 & 88.992 .080 & 477.874 .816 & 35.596 .832 \\
\hline 4.a & $\begin{array}{l}\text { Excavation } \\
\text { (Penggalian) }\end{array}$ & 1750 & 5 & 2.876 .201 & 1 & 700 & 3 & 4.844 .128 & 12.110 .320 & 80.220 .640 & 4.844 .128 \\
\hline 4.c & $\begin{array}{l}\text { Fell and Compaction } \\
\text { (Menimbun dan } \\
\text { Memadatkan Tanah) }\end{array}$ & 1750 & 5 & 21.134 .752 & 1 & 700 & 3 & 35.596 .832 & 88.992 .080 & 295.863 .576 & 35.596 .832 \\
\hline $5 . \mathrm{a}$ & $\begin{array}{l}\text { Excavation } \\
\text { (Penggalian) }\end{array}$ & 1750 & 3 & 2.876 .201 & 1 & 1166,67 & 2 & 4.844 .128 & 7.266.192 & 70.532 .384 & 4.844 .128 \\
\hline 5.c & $\begin{array}{l}\text { Fell and Compaction } \\
\text { (Menimbun dan } \\
\text { Memadatkan Tanah) }\end{array}$ & 1750 & 5 & 21.134 .752 & 1 & 700 & 3 & 35.596 .832 & 88.992 .080 & 295.863 .576 & 35.596 .832 \\
\hline $6 . \mathrm{a}$ & $\begin{array}{l}\text { Excavation } \\
\text { (Penggalian) }\end{array}$ & 1750 & 3 & 2.876 .201 & 1 & 1166,67 & 2 & 4.844 .128 & 7.266 .192 & 70.532 .384 & 4.844 .128 \\
\hline 6.c & $\begin{array}{l}\text { Fell and Compaction } \\
\text { (Menimbun dan } \\
\text { Memadatkan Tanah) }\end{array}$ & 1750 & 5 & 21.134 .752 & 1 & 700 & 3 & 35.596 .832 & 88.992 .080 & 295.863 .576 & 35.596 .832 \\
\hline 7.a & $\begin{array}{l}\text { Excavation } \\
\text { (Penggalian) }\end{array}$ & 1750 & 3 & 2.876 .201 & 1 & 1166,67 & 2 & 4.844 .128 & 7.266 .192 & 70.532 .384 & 4.844 .128 \\
\hline 7.c & $\begin{array}{l}\text { Fell and Compaction } \\
\text { (Menimbun dan } \\
\text { Memadatkan Tanah) }\end{array}$ & 1750 & 5 & 21.134 .752 & 1 & 700 & 3 & 35.596 .832 & 88.992 .080 & 295.863 .576 & 35.596 .832 \\
\hline $8 . \mathrm{a}$ & $\begin{array}{l}\text { Excavation } \\
\text { (Penggalian) }\end{array}$ & 1750 & 3 & 2.876 .201 & 1 & 1166,67 & 2 & 4.844 .128 & 7.266.192 & 70.532 .384 & 4.844 .128 \\
\hline
\end{tabular}


Tabel 3.2 Rekapitulasi Crash Duration Crash Cost dan Cost Slope Alternatif 2 Pekerjaan Lintasan Kritis (Lanjutan)

\begin{tabular}{|c|c|c|c|c|c|c|c|c|c|c|c|}
\hline No & Pekerjaan & Volume & $\begin{array}{c}\text { Durasi } \\
\text { Normal } \\
\text { (Hari) }\end{array}$ & $\begin{array}{l}\text { Total Upah } \\
\text { Grup/Hari }\end{array}$ & + Grup & $\begin{array}{l}\text { Produktivitas } \\
\text { +Grup }\end{array}$ & $\begin{array}{c}\text { Crash } \\
\text { Duration } \\
\text { (Hari) }\end{array}$ & $\begin{array}{l}\text { Total Upah } \\
\text { +Grup/Hari } \\
\text { (Rp) }\end{array}$ & Crash Cost (Rp) & $\begin{array}{l}\text { Crash Cost } \\
\text { Total (Rp) }\end{array}$ & $\begin{array}{c}\text { Cost Slope } \\
\text { (Rp) }\end{array}$ \\
\hline 8.c & $\begin{array}{l}\text { Fell and Compaction } \\
\text { (Menimbun dan } \\
\text { Memadatkan Tanah) }\end{array}$ & 1750 & 5 & 21.134 .752 & 1 & 700 & 3 & 35.596 .832 & 88.992 .080 & 295.863 .576 & 35.596 .832 \\
\hline 9.a & $\begin{array}{l}\text { Excavation } \\
\text { (Penggalian) }\end{array}$ & 1750 & 3 & 2.876 .201 & 1 & 1166,67 & 2 & 4.844 .128 & 7.266 .192 & 70.532 .384 & 4.844 .128 \\
\hline 9.c & $\begin{array}{l}\text { Fell and Compaction } \\
\text { (Menimbun dan } \\
\text { Memadatkan Tanah) }\end{array}$ & 1750 & 5 & 21.134 .752 & 1 & 700 & 3 & 35.596 .832 & 88.992 .080 & 295.863 .576 & 35.596 .832 \\
\hline 10.a & $\begin{array}{l}\text { Excavation } \\
\text { (Penggalian) }\end{array}$ & 1750 & 3 & 2.876 .201 & 1 & 1166,67 & 2 & 4.844 .128 & 7.266 .192 & 70.532 .384 & 4.844 .128 \\
\hline $10 . c$ & $\begin{array}{l}\text { Fell and Compaction } \\
\text { (Menimbun dan } \\
\text { Memadatkan Tanah) }\end{array}$ & 1750 & 5 & 21.134 .752 & 1 & 700 & 3 & 35.596 .832 & 88.992 .080 & 295.863 .576 & 35.596 .832 \\
\hline 11.a & $\begin{array}{l}\text { Excavation } \\
\text { (Penggalian) }\end{array}$ & 1750 & 3 & 2.876 .201 & 1 & 1166,67 & 2 & 4.844 .128 & 7.266 .192 & 70.532 .384 & 4.844 .128 \\
\hline 11.c & $\begin{array}{l}\text { Fell and Compaction } \\
\text { (Menimbun dan } \\
\text { Memadatkan Tanah) }\end{array}$ & 1750 & 5 & 2.876 .201 & 1 & 1166,67 & 2 & 4.844 .128 & 7.266 .192 & 70.532 .384 & 4.844 .128 \\
\hline 12 & $\begin{array}{l}\text { Soil Dirt Hauling } \\
\text { (Pemindahan Tanah } \\
\text { Non-HIS ke Borrow } \\
\text { Pit Area) }\end{array}$ & 14.406 & 16 & 10.749 .128 & 1 & 1800,75 & 8 & 21.498 .256 & 171.986 .048 & 1.117 .959 .376 & 21.498 .256 \\
\hline 13 & $\begin{array}{l}\text { Remove HIS to SBF } \\
\text { (Pemindahan Tanah } \\
\text { Terkontaminasi ke } \\
\text { Penampungan } \\
\text { Sementara) } \\
\end{array}$ & 3601,44 & 4 & 10.749 .128 & 1 & 1800,72 & 2 & 21.498 .256 & 42.996 .512 & Rp.436.706.080 & 21.498 .256 \\
\hline 14 & $\begin{array}{l}\text { Dress and Compaction } \\
\text { (Merapikan Daerah } \\
\text { yang sudah Tidak } \\
\text { Terkontaminasi) }\end{array}$ & 12.000 & 5 & 4.149 .232 & 1 & 4800 & 3 & 8.298 .464 & 20.746 .160 & Rp 82.292.320 & 8.298 .464 \\
\hline
\end{tabular}



dalam Bidang Teknik Industri

Tabel 3.3 Rekapitulasi Crash Duration Crash Cost dan Cost Slope Alternatif 3 Pekerjaan Lintasan Kritis

\begin{tabular}{|c|c|c|c|c|c|c|c|c|c|c|}
\hline No & Pekerjaan & Volume & $\begin{array}{c}\text { Durasi } \\
\text { Normal } \\
\text { (Hari) }\end{array}$ & $\begin{array}{c}\text { Jumlah } \\
+ \text { Alat }\end{array}$ & $\begin{array}{c}\text { Total } \\
\text { Kapasitas } \\
\text { Alat/Hari }\end{array}$ & $\begin{array}{c}\text { Crash } \\
\text { Duration } \\
\text { (Hari) }\end{array}$ & $\begin{array}{l}\text { Total Biaya } \\
\text { +Alat (Rp) }\end{array}$ & $\begin{array}{l}\text { Crash Cost } \\
\quad(\mathrm{Rp})\end{array}$ & $\begin{array}{l}\text { Crash Cost } \\
\text { Total (Rp) }\end{array}$ & $\begin{array}{c}\text { Cost Slope } \\
(\mathrm{Rp})\end{array}$ \\
\hline 2.e & $\begin{array}{l}\text { Clearing and } \\
\text { Grubbing } \\
\text { (Pembersihan Area) }\end{array}$ & 17539 & 7 & 2 & 2744,72 & 6 & 9.054 .336 & 57.857 .996 & 216.069 .028 & 94.862 .727 \\
\hline $3 . \mathrm{a}$ & $\begin{array}{l}\text { Excavation } \\
\text { (Penggalian) }\end{array}$ & 4200 & 5 & 1 & 955,68 & 4 & 4.227 .168 & 18.577 .459 & 165.087 .779 & R30.695.203 \\
\hline 3.b & $\begin{array}{l}\text { Fell and Compaction } \\
\text { (Menimbun dan } \\
\text { Memadatkan Tanah) }\end{array}$ & 4200 & 5 & 2 & 2744,72 & 2 & 9.054 .336 & 13.855 .042 & 402.737 .778 & 3.993 .050 \\
\hline 4.a & $\begin{array}{l}\text { Excavation } \\
\text { (Penggalian) }\end{array}$ & 1750 & 5 & 1 & 955,68 & 2 & 4.227 .168 & 7.740 .608 & 75.850 .928 & 2.442 .724 \\
\hline 4.c & $\begin{array}{l}\text { Fell and Compaction } \\
\text { (Menimbun dan } \\
\text { Memadatkan Tanah) }\end{array}$ & 1750 & 5 & 2 & 2744,72 & 1 & 9.054 .336 & 9.054 .336 & 215.925 .832 & 2.263 .854 \\
\hline $5 . \mathrm{a}$ & $\begin{array}{l}\text { Excavation } \\
\text { (Penggalian) }\end{array}$ & 1750 & 3 & 1 & 955,68 & 2 & 4.227 .168 & 7.740 .608 & 71.006 .800 & 6.622 .452 \\
\hline 5.c & $\begin{array}{l}\text { Fell and Compaction } \\
\text { (Menimbun dan } \\
\text { Memadatkan Tanah) }\end{array}$ & 1750 & 5 & 2 & 2744,72 & 1 & 9.054 .336 & 9.054 .336 & 215.925 .832 & 2.263 .854 \\
\hline $6 . \mathrm{a}$ & $\begin{array}{l}\text { Excavation } \\
\text { (Penggalian) }\end{array}$ & 1750 & 3 & 1 & 955,68 & 2 & 4.227 .168 & 7.740 .608 & 71.006 .800 & 6.622 .452 \\
\hline $6 . c$ & $\begin{array}{l}\text { Fell and Compaction } \\
\text { (Menimbun dan } \\
\text { Memadatkan Tanah) }\end{array}$ & 1750 & 5 & 2 & 2744,72 & 1 & 9.054 .336 & 9.054 .336 & 215.925 .832 & 2.263 .854 \\
\hline 7.a & $\begin{array}{l}\text { Excavation } \\
\text { (Penggalian) }\end{array}$ & 1750 & 3 & 1 & 955,68 & 2 & 4.227 .168 & 7.740 .608 & 71.006 .800 & 6.622 .452 \\
\hline 7.c & $\begin{array}{l}\text { Fell and Compaction } \\
\text { (Menimbun dan } \\
\text { Memadatkan Tanah) }\end{array}$ & 1750 & 5 & 2 & 2744,72 & 1 & 9.054 .336 & R9.054.336 & 215.925 .832 & 2.263 .854 \\
\hline 8.a & $\begin{array}{l}\text { Excavation } \\
\text { (Penggalian) }\end{array}$ & 1750 & 3 & 1 & 955,68 & 2 & 4.227.168 & 7.740 .608 & 71.006 .800 & 6.622 .452 \\
\hline
\end{tabular}


Tabel 3.3 Rekapitulasi Crash Duration Crash Cost dan Cost Slope Alternatif 3 Pekerjaan Lintasan Kritis (Lanjutan)

\begin{tabular}{|c|c|c|c|c|c|c|c|c|c|c|}
\hline No & Pekerjaan & Volume & $\begin{array}{c}\text { Durasi } \\
\text { Normal } \\
\text { (Hari) }\end{array}$ & $\begin{array}{c}\text { Jumlah } \\
+ \text { Alat }\end{array}$ & $\begin{array}{c}\text { Total } \\
\text { Kapasitas } \\
\text { Alat/Hari }\end{array}$ & $\begin{array}{c}\text { Crash } \\
\text { Duration } \\
\text { (Hari) }\end{array}$ & $\begin{array}{l}\text { Total Biaya } \\
+ \text { Alat (Rp) }\end{array}$ & $\begin{array}{l}\text { Crash Cost } \\
(\mathrm{Rp})\end{array}$ & $\begin{array}{c}\text { Crash Cost Total } \\
(\mathrm{Rp})\end{array}$ & $\begin{array}{l}\text { Cost Slope } \\
\text { (Rp) }\end{array}$ \\
\hline 8.c & $\begin{array}{l}\text { Fell and Compaction } \\
\text { (Menimbun dan } \\
\text { Memadatkan Tanah) }\end{array}$ & 1750 & 5 & 2 & 2744,72 & 1 & 9.054 .336 & 9.054 .336 & 215.925 .832 & 2.263 .854 \\
\hline 9.a & $\begin{array}{l}\text { Excavation } \\
\text { (Penggalian) }\end{array}$ & 1750 & 3 & 1 & 955,68 & 2 & 4.227 .168 & 7.740 .608 & 71.006 .800 & 6.622 .452 \\
\hline 9.c & $\begin{array}{l}\text { Fell and Compaction } \\
\text { (Menimbun dan } \\
\text { Memadatkan Tanah) }\end{array}$ & 1750 & 5 & 2 & 2744,72 & 1 & 9.054 .336 & 9.054 .336 & 215.925 .832 & 2.263 .854 \\
\hline $10 . a$ & $\begin{array}{l}\text { Excavation } \\
\text { (Penggalian) }\end{array}$ & 1750 & 3 & 1 & 955,68 & 2 & 4.227 .168 & 7.740 .608 & 71.006 .800 & 6.622 .452 \\
\hline 10.c & $\begin{array}{l}\text { Fell and Compaction } \\
\text { (Menimbun dan } \\
\text { Memadatkan Tanah) }\end{array}$ & 1750 & 5 & 2 & 2744,72 & 1 & 9.054 .336 & 9.054 .336 & 215.925 .832 & 2.263 .854 \\
\hline 11.a & $\begin{array}{l}\text { Excavation } \\
\text { (Penggalian) }\end{array}$ & 1750 & 3 & 1 & 955,68 & 2 & 4.227 .168 & 7.740 .608 & 71.006 .800 & 6.622 .452 \\
\hline 11.c & $\begin{array}{l}\text { Fell and Compaction } \\
\text { (Menimbun dan } \\
\text { Memadatkan Tanah) }\end{array}$ & 1750 & 5 & 2 & 2744,72 & 1 & 9.054 .336 & 9.054 .336 & 215.925 .832 & 2.263 .854 \\
\hline 12 & $\begin{array}{l}\text { Soil Dirt Hauling } \\
\text { (Pemindahan Tanah } \\
\text { Non-HIS ke Borrow } \\
\text { Pit Area) }\end{array}$ & 14.406 & 16 & 1 & 955,68 & 15 & 6.027 .168 & 90.854 .033 & 1.036 .827 .361 & 98.123 .341 \\
\hline 13 & $\begin{array}{l}\text { Remove HIS to SBF } \\
\text { (Pemindahan Tanah } \\
\text { Terkontaminasi ke } \\
\text { Penampungan } \\
\text { Sementara) }\end{array}$ & 3601,44 & 4 & 1 & 955,68 & 3 & 4.227 .168 & 12.681 .504 & 406.391 .072 & 12.681 .504 \\
\hline 14 & $\begin{array}{l}\text { Dress and } \\
\text { Compaction } \\
\text { (Merapikan Daerah } \\
\text { yang sudah Tidak } \\
\text { Terkontaminasi) } \\
\end{array}$ & 12.000 & 5 & 2 & 8287,17 & 1 & 6.874 .336 & 9.954 .188 & 71.500 .348 & 2.802 .435 \\
\hline
\end{tabular}




\section{Time Cost Trade Off}

1. Tahap Normal

a. Durasi Normal

b. Biaya Overhead $=\operatorname{Rp} 2.922 .092$

Tabel 3.4 Rekapitulasi Biaya Overhead

\begin{tabular}{|c|r|}
\hline Nama Pekerjaan & $\begin{array}{r}\text { Upah/Hari } \\
\text { Rp }\end{array}$ \\
\hline Project Manager & 805.833 \\
\hline Site Sup't & 543.904 \\
\hline Project Control & 241.881 \\
\hline Survey Supv & 221.746 \\
\hline Earthwork Supv & 221.746 \\
\hline HES Supv & 221.746 \\
\hline Finance Supv & 221.746 \\
\hline HRD Supv & 221.746 \\
\hline Equipment Supv & 221.746 \\
\hline Overhead/Hari & $\mathbf{2 . 9 2 2 . 0 9 2}$ \\
\hline
\end{tabular}

c. $\quad$ Profit $=$ Rp 321.342.521

d. Biaya Tidak Langsung $=\operatorname{Rp} 671.993 .561$

e. $\quad$ Biaya Langsung $=\operatorname{Rp} 4.277 .894 .663$

f. $\quad$ Total Cost $=\mathrm{Rp}$ 4.949.888.224

2. Pekerjaan Clearing and Grubbing (Pembersihan Area)

a. Cost Slope $=\mathrm{Rp}$ 5.403.867

b. Durasi Normal $=7$ Hari

c. Crash Duration $=6$ Hari

d. Total Crash = Durasi Normal - Crash Duration $=7$ hari -6 Hari $=1$ Hari

e. Total Durasi Proyek

$=$ Durasi Normal Proyek - Total Crash

= 120 Hari -1 Hari

$=119$ Hari

f. Penambahan Biaya

= Cost Slope $\mathrm{x}$ Total Crash

$=\operatorname{Rp} 5.403 .867 \times 1$

$=\operatorname{Rp} 5.403 .867$

g. Biaya Langsung

= Biaya Lansung + Penambahan Biaya

$=\operatorname{Rp} 4.277 .894 .663+\operatorname{Rp~5.403.867}$

$=\operatorname{Rp} 4.283 .298 .530$

h. Biaya Lembur = Rp 6.011.809

g. Biaya Tidak Langsung

$=($ Total Durasi Proyek x Biaya Overhead $)+$ Profit + Biaya Lembur

$=(119$ Hari $\mathrm{x}$ Rp 2.922.092) + Rp

$321.342 .521+\mathrm{Rp} 6.011 .809$

$=\operatorname{Rp} 675.083 .278$

j. Total Cost

= Biaya Langsung + Biaya Tidak Langsung

$=\operatorname{Rp} 4.277 .894 .663+\operatorname{Rp} 675.083 .278$

$=\operatorname{Rp} 4.952 .977 .941$
Tabel 3.5 Rekapitulasi Perhitungan Biaya Total Penambahan Jam Kerja

\begin{tabular}{|c|c|c|c|}
\hline $\begin{array}{c}\text { Durasi } \\
\text { (Hari) }\end{array}$ & $\begin{array}{c}\text { Biaya } \\
\text { Langsung } \\
(\mathrm{Rp})\end{array}$ & $\begin{array}{c}\text { Biaya Tidak } \\
\text { Langsung } \\
(\mathrm{Rp})\end{array}$ & $\begin{array}{c}\text { Biaya Total } \\
(\mathrm{Rp})\end{array}$ \\
\hline 119 & 4.283 .298 .530 & 675.083 .278 & 4.952 .977 .941 \\
\hline 118 & 4.280 .124 .826 & 669.025 .578 & 4.946 .920 .241 \\
\hline 117 & 4.299 .006 .434 & 684.339 .060 & 4.962 .233 .723 \\
\hline 116 & 4.280 .770 .860 & 663.181 .394 & 4.941 .076 .057 \\
\hline 115 & 4.299 .029 .411 & 678.517 .853 & 4.956 .412 .516 \\
\hline
\end{tabular}

Tabel 3.6 Rekapitulasi Perhitungan Biaya Total Penambahan Jam Kerja

\begin{tabular}{|c|c|c|c|}
\hline $\begin{array}{c}\text { Durasi } \\
\text { (Hari) }\end{array}$ & $\begin{array}{c}\text { Biaya } \\
\text { Langsung } \\
(\mathrm{Rp})\end{array}$ & $\begin{array}{c}\text { Biaya Tidak } \\
\text { Langsung } \\
(\mathrm{Rp})\end{array}$ & $\begin{array}{c}\text { Biaya Total } \\
(\mathrm{Rp})\end{array}$ \\
\hline 114 & 4.280 .770 .862 & 657.337 .210 & 4.935 .231 .873 \\
\hline 113 & 4.299 .029 .411 & 672.673 .669 & 4.950 .568 .332 \\
\hline 112 & 4.280 .770 .862 & 651.493 .026 & 4.929 .387 .689 \\
\hline 111 & 4.299 .029 .411 & 666.829 .485 & 4.944 .724 .148 \\
\hline 110 & 4.280 .770 .862 & 645.648 .842 & 4.923 .543 .505 \\
\hline 109 & 4.299 .029 .411 & 660.985 .301 & 4.938 .879 .964 \\
\hline 108 & 4.280 .770 .862 & 639.804 .658 & 4.917 .699 .321 \\
\hline 107 & 4.299 .029 .411 & 655.141 .117 & 4.933 .035 .780 \\
\hline 106 & 4.280 .770 .862 & 633.960 .474 & 4.911 .855 .137 \\
\hline 105 & 4.299 .029 .411 & 649.296 .933 & 4.948 .303 .367 \\
\hline 104 & 4.280 .770 .862 & 628.116 .290 & 4.906 .010 .953 \\
\hline 103 & 4.299 .029 .411 & 643.452 .749 & 4.921 .347 .412 \\
\hline $\mathbf{1 0 2}$ & $\mathbf{4 . 2 8 0 . 7 7 0 . 8 6 2}$ & $\mathbf{6 2 2 . 2 7 2 . 1 0 6}$ & $\mathbf{4 . 9 0 0 . 1 6 6 . 7 6 9}$ \\
\hline 101 & 4.299 .029 .411 & 637.608 .565 & 4.915 .503 .228 \\
\hline 99 & 4.303 .423 .815 & 623.394 .219 & 4.901 .288 .882 \\
\hline
\end{tabular}

Tabel 3.7 Rekapitulasi Perhitungan Biaya Total Penambahan Grup Kerja

\begin{tabular}{|c|c|c|c|}
\hline $\begin{array}{c}\text { Durasi } \\
\text { (Hari) }\end{array}$ & $\begin{array}{c}\text { Bangsung } \\
\text { (Rp) }\end{array}$ & $\begin{array}{c}\text { Biaya Tidak } \\
\text { Langsung } \\
(\mathrm{Rp})\end{array}$ & $\begin{array}{c}\text { Biaya Total } \\
\text { (Rp) }\end{array}$ \\
\hline 117 & 4.308 .270 .119 & 673.352 .437 & 4.951 .247 .100 \\
\hline 115 & 4.287 .582 .919 & 662.227 .229 & 4.940 .121 .892 \\
\hline 113 & 4.349 .088 .327 & 687.135 .749 & 4.965 .030 .412 \\
\hline 111 & 4.287 .582 .919 & 650.538 .861 & 4.928 .433 .524 \\
\hline 109 & 4.349 .088 .327 & 675.447 .381 & 4.953 .342 .044 \\
\hline 108 & 4.282 .738 .791 & 641.772 .585 & 4.919 .667 .248 \\
\hline 106 & 4.349 .088 .327 & 666.681 .105 & 4.944 .575 .768 \\
\hline $\mathbf{1 0 5}$ & $\mathbf{4 . 2 8 0 . 7 7 0 . 8 6 2}$ & $\mathbf{6 3 1 . 0 3 8 . 3 8 0}$ & $\mathbf{4 . 9 0 8 . 9 3 3 . 0 4 3}$ \\
\hline 103 & 4.320 .164 .159 & 643.452 .745 & 4.921 .347 .408 \\
\hline
\end{tabular}

Tabel 3.8 Rekapitulasi Perhitungan Biaya Total Penambahan Kapasitas Alat

\begin{tabular}{|c|c|c|c|}
\hline $\begin{array}{c}\text { Durasi } \\
\text { (Hari) }\end{array}$ & $\begin{array}{c}\text { Biaya } \\
\text { Langsung } \\
(\mathrm{Rp})\end{array}$ & $\begin{array}{c}\text { Biaya Tidak } \\
\text { Langsung } \\
(\mathrm{Rp})\end{array}$ & $\begin{array}{c}\text { Biaya Total } \\
(\mathrm{Rp})\end{array}$ \\
\hline 119 & 4.372 .757 .390 & 678.125 .805 & 4.956 .020 .468 \\
\hline 118 & 4.308 .589 .866 & 670.376 .545 & 4.948 .271 .208 \\
\hline 115 & 4.289 .873 .813 & 666.437 .437 & 4.944 .332 .100 \\
\hline 112 & 4.285 .222 .835 & 652.843 .993 & 4.930 .738 .656 \\
\hline 111 & 4.280 .518 .247 & 654.749 .069 & 4.932 .643 .732 \\
\hline 110 & 4.284 .517 .115 & 646.999 .809 & 4.924 .894 .472 \\
\hline 109 & 4.287 .653 .475 & 648.904 .885 & 4.926 .799 .548 \\
\hline 108 & 4.284 .517 .115 & 641.155 .625 & 4.919 .050 .288 \\
\hline 107 & 4.287 .653 .475 & 643.060 .701 & 4.920 .955 .364 \\
\hline
\end{tabular}




\begin{tabular}{|c|c|c|c|}
\hline 106 & 4.284 .517 .115 & 635.311 .441 & 4.913 .206 .104 \\
\hline 105 & 4.287 .653 .475 & 637.216 .517 & 4.915 .111 .180 \\
\hline 104 & 4.284 .517 .115 & 629.467 .257 & 4.907 .361 .920 \\
\hline 103 & 4.287 .653 .475 & 631.372 .333 & 4.909 .266 .996 \\
\hline 102 & 4.284 .517 .115 & 623.623 .073 & 4.901 .517 .736 \\
\hline 101 & 4.287 .653 .475 & 625.528 .149 & 4.915 .401 .962 \\
\hline $\mathbf{1 0 0}$ & $\mathbf{4 . 2 8 4 . 5 1 7 . 1 1 5}$ & $\mathbf{6 1 7 . 7 7 8 . 8 8 9}$ & $\mathbf{4 . 8 9 5 . 6 7 3 . 5 5 2}$ \\
\hline 99 & 4.287 .653 .475 & 619.683 .965 & 4.897 .578 .628 \\
\hline
\end{tabular}

\section{Kesimpulan}

Berdasarkan hasil analisis dan tujuan yang telah ditetapkan pada proyek Access Road Construction and Soil Clean Up, diperoleh kesimpulan yaitu :

1. Durasi dan biaya yang optimal dalam penyelesaian proyek pada masing-masing alternatif, yaitu :

a. Alternatif 1 (penambahan jam kerja) dengan durasi 102 hari kerja dan biaya total proyek Rp 4.900.166.769.

b. Alternatif 2 (penambahan grup kerja) dengan durasi 105 hari kerja dan biaya total proyek Rp 4.908.933.043.

c. Alternatif 3 (penambahan alat) dengan durasi 100 hari kerja dan biaya total proyek Rp 4.895.673.552.

2. Berdasarkan perbandingan diatas, maka dapat dilihat waktu dan biaya yang optimal untuk proyek yaitu dengan melakukan penambahan alat dengan durasi proyek 100 hari kerja dengan biaya total $\mathrm{Rp}$ 4.895.673.552.

\section{Daftar Pustaka}

Dannyanti, E., 2010. Optimalisasi Pelaksanaan Proyek dengan Metode PERT dan CPM (Studi Kasus: Twin Tower BuildingPasca Sarjana Undip). Fakultas Ekonomi Universitas Diponegoro.

Djajalaksana, YM., Toba, H., Emanuel, AWR., 2009. Panduan Lengkap Mengelola Proyek dengan Microsoft Project Profesional 2007. Graha Ilmu. Yogyakarta : 2009.

Dundu, AKT., Tjakara, J., Paath., PC., 2015. Analisis Pengendalian Bahan Proyek Pembangunan Dengan Metode Goal Programming Prioritas (Studi Kasus:Proyek Pembangunan Gedung Sekolah Eben Haezar). Jurnal Sipil Satatik Vol.3 No.5 Mei 2015 (351-360) ISSN:2337-6732. Fakultas Teknik Jurusan Teknik Sipil Universitas Sam Ratulangi Manado.

Husen, Ir Abrar., 2008. Manajemen Proyek. Penerbit Andi. Yogyakarta : 2009.
Limanto, S., Marsiano, F., Wijaya, GD., 2012. Penjadwalan Proyek Rumah Toko Menggunakan Microsoft Project 2010.

Malingkas., J.Tjakara., Mandagi, RJM., 2012. Perencanaan Dan Pengendalian Jadwal dengan Menggunakan Program Microst Project 2010 (Studi Kasus: Proyek PT.Trakindo Utama). Jurnal Sipil Statik Vol.1 No.1, November 2012 (22-26). Jurusan Teknik Sipil Universitas Sam Ratulangi.

Nurhayati., 2010. Manajemen Proyek. Graha Ilmu. Yogyakarta : 2010.

Soeharto, Imam., 1998. Manajemen Proyek Jilid 2. Penerbit Erlangga. Jakarta

Yana, AA., 2006. Pengaruh Jam Kerja Lembur Terhadap Biaya Percepatan Proyek dengan Time Cost Trade Off (Studi Kasus:Proyek Rehabilitasi Ruang Pertemuan Dinas Pertanian Tanaman Pangan Provinsi Bali). Jurnal Ilmiah Teknik Sipil Vol.10, No.2, Juli 2006. Fakultas Teknik Universitas Udayana Denpasar. 